\title{
NAD- and NADPH-Contributing Enzymes as Therapeutic Targets in Cancer: An Overview
}

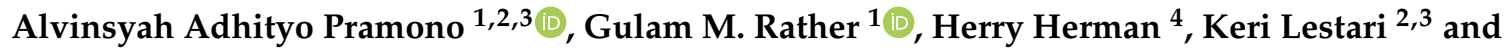 \\ Joseph R. Bertino 1,5,* \\ 1 Rutgers Cancer Institute of New Jersey, Rutgers, The State University of New Jersey, \\ New Brunswick, NJ 08901, USA; alvinsyah.pramono@rutgers.edu (A.A.P.); gmr112@cinj.rutgers.edu (G.M.R.) \\ 2 Department of Pharmacology and Clinical Pharmacy, Faculty of Pharmacy, Universitas Padjadjaran, \\ Sumedang 45363, Indonesia; lestarikd@unpad.ac.id \\ 3 Center of Excellence in Higher Education for Pharmaceutical Care Innovation, Universitas Padjadjaran, \\ Sumedang 45363, Indonesia \\ 4 Division of Oncology, Department of Orthopaedic Surgery, Faculty of Medicine, Universitas Padjadjaran, \\ Bandung 40161, Indonesia; herry_herman@yahoo.com \\ 5 Department of Pharmacology and Medicine, Robert Wood Johnson Medical School, Rutgers, The State \\ University of New Jersey, New Brunswick, NJ 08901, USA \\ * Correspondence: bertinoj@cinj.rutgers.edu; Tel.: +1-(732)-235-8510
}

Received: 27 January 2020; Accepted: 21 February 2020; Published: 26 February 2020

check for updates

\begin{abstract}
Actively proliferating cancer cells require sufficient amount of NADH and NADPH for biogenesis and to protect cells from the detrimental effect of reactive oxygen species. As both normal and cancer cells share the same NAD biosynthetic and metabolic pathways, selectively lowering levels of NAD $(\mathrm{H})$ and NADPH would be a promising strategy for cancer treatment. Targeting nicotinamide phosphoribosyltransferase (NAMPT), a rate limiting enzyme of the NAD salvage pathway, affects the NAD and NADPH pool. Similarly, lowering NADPH by mutant isocitrate dehydrogenase 1/2 (IDH1/2) which produces D-2-hydroxyglutarate (D-2HG), an oncometabolite that downregulates nicotinate phosphoribosyltransferase (NAPRT) via hypermethylation on the promoter region, results in epigenetic regulation. NADPH is used to generate D-2HG, and is also needed to protect dihydrofolate reductase, the target for methotrexate, from degradation. NAD and NADPH pools in various cancer types are regulated by several metabolic enzymes, including methylenetetrahydrofolate dehydrogenase, serine hydroxymethyltransferase, and aldehyde dehydrogenase. Thus, targeting NAD and NADPH synthesis under special circumstances is a novel approach to treat some cancers. This article provides the rationale for targeting the key enzymes that maintain the NAD/NADPH pool, and reviews preclinical studies of targeting these enzymes in cancers.
\end{abstract}

Keywords: NAMPT inhibitor; NADK inhibitor; dihydrofolate reductase; IDH mutation; NAD/NADPH pool

\section{Introduction}

Sensitizing cancer cells to lower levels of NAD and NADPH pool without affecting normal cells is a novel anti-cancer strategy. The interdependence of different pathways of the pool is a difficult challenge to target them separately. Nicotinamide phosphoribosyltransferase (NAMPT), the rate-limiting enzyme of NAD salvage pathway, is the greatest contributor in generating NAD in mammals [1,2]. Overexpression of NAMPT has been implicated in several cancers [3-5]. On the other hand, nicotinate phosphoribosyltransferase (NAPRT) also produces NAD through the nicotinic acid pathway $[1,6]$. However, recent studies have shown that isocitrate dehydrogenase (IDH) mutations may result in downregulation of NAPRT [7-9]. 
NADPH is essential in controlling high levels of reactive oxygen species (ROS) in rapidly proliferating cancer cells [10] and in protecting dihydrofolate reductase (DHFR) from degradation [11]. Finally, NADPH is used to generate the oncometabolite D-2-hydroxyketoglutarate (D-2HG) [12,13]. These findings have stimulated efforts to target these pathways in cancer cells. In this review, we describe the approaches to lowering NAD and NADPH levels or both in many types of cancer that may allow for selective toxicity.

\section{Targeting NAD Synthesis}

Cancer cells produce energy through aerobic glycolysis rather than conventionally developing energy through the citric acid cycle and respiratory chain, a phenomenon known as the Warburg effect [14]. Aerobic glycolysis requires NAD as electron recipient during glyceraldehyde-3-phosphate dehydrogenase (GAPDH) catalysis of glyceraldehyde-3-phospate into diphosphoglycerate, and generates inorganic phosphate for ATP production. Gluconeogenesis utilization also requires NAD which is converted to NADPH during the cytosolic conversation of malate intermediate into oxaloacetate. NAD depletion is seen as disaster for cancer cells, as both glucose production and glucose utilization will come to a halt. The amount of energy produced from aerobic glycolysis is less than the energy produced by the normal respiratory chain. However, cancer cells are able to produce significant amount of energy and biomass to support cancer survival in a short period of time $[6,14,15]$.

When cancer cells become quiescent, the citric acid cycle and electron transport chain are preferred compared to aerobic glycolysis [16]. Excessive amount of NADH obtained from glycolysis is utilized to convert dihydroxyacetone phosphate (DHAP) into glycerol-3-phosphate (G3P). G3P donates electrons for the oxidative phosphorylation to maintain mitochondrial integrity and ATP production in quiescent cancer cells [16]. Recent evidence showed that oxidative phosphorylation is upregulated in some cancers, including breast cancer, Hodgkin lymphoma and RB1-deficient cancers [17-21]. These results indicated that targeting NADH pool could affect oxidative phosphorylation in these cancer types [16,22].

NAD levels in cancer cells are generated through three separate pathways: the nicotinic acid (NA) pathway, the de novo pathway and the NAD salvage pathway (Figure 1) $[6,23]$. The precursors for NA and the de novo pathway are nicotinic acid and dietary tryptophan, respectively [24,25]. NAPRT converts NA into nicotinic acid mononucleotide (NAMN). Tryptophan, is converted to quinolinic acid, and is incorporated into the NA pathway as NAMN to generate NAD. Sirtuins, poly (ADP-ribose) polymerases (PARPs) and CD157, NAD consumers, recycle NAD by providing nicotinamide (Nam) as the precursor of the NAD salvage pathway. The NAD salvage pathway is the major source of NAD in humans that depends on NAMPT, as it is the rate-limiting enzyme [26].

Despite conventional pathways that have been explored, Charles Brenner found a new mechanism of generating NAD using synthetic precursors following the emergence of vitamin B3 supplementation to prevent pellagra in 2004 [27]. Both nicotinamide riboside (NR) and nicotinic acid riboside (NAR) are exogenous sources of NAD production [28]. NR is incorporated to the NAD salvage pathway after conversion to nicotinamide mononucleotide (NMN) $[28,29]$. NAR becomes a part of the NA pathway after it is converted to NAMN [28,29]. Both reactions are catalyzed by nicotinamide riboside kinase 1/2 (NRK1/2) [27-29] (Figure 1). NMN supplementation is also available, however in order to be internalized in the cell, it has been postulated that NMN must be converted to NR by cell membrane protein CD73 (also known as ecto-5-nucleotidase) [28,30].

Early on, elevated NAD levels exert a protective effect against oncogenesis [31-34], later on, elevated NAD levels enhance cancer cell survival and progression [35-37]. Demonstrating the effect of restricting the NAD pool in halting cancer progression requires the inhibition of vital pathways, and the reduction of redundancy [38]. This may be achieved in cancer cells that are deficient in one of the NAD biogenesis pathways.

Some cancers, such as glioblastoma, chondrosarcoma, leukemia and colorectal cancer, have mutations in isocitrate dehydrogenase 1/2 (IDH1/2) [13,39-41]. Mutant IDH1/2 uses NADPH to convert $\alpha$-ketoglutarate $(\alpha-\mathrm{KG})$ into D-2HG, an oncometabolite that causes hypermethylation at 
CpG islands or loss of exon 1 expression in NAPRT [7-9,39,40]. As a consequence, inhibition of NAPRT enzyme activity forces these cells to mainly depend on the NAD salvage pathway to generate NAD (Figure 1) [7]. Furthermore, NAMPT is frequently amplified in some cancers which may also affect the NAD pool $[3,7,42,43]$. Conversely, NAMPT-specific inhibitors significantly deplete NAD levels and subsequently suppress cancer cell proliferation [7,44-46].

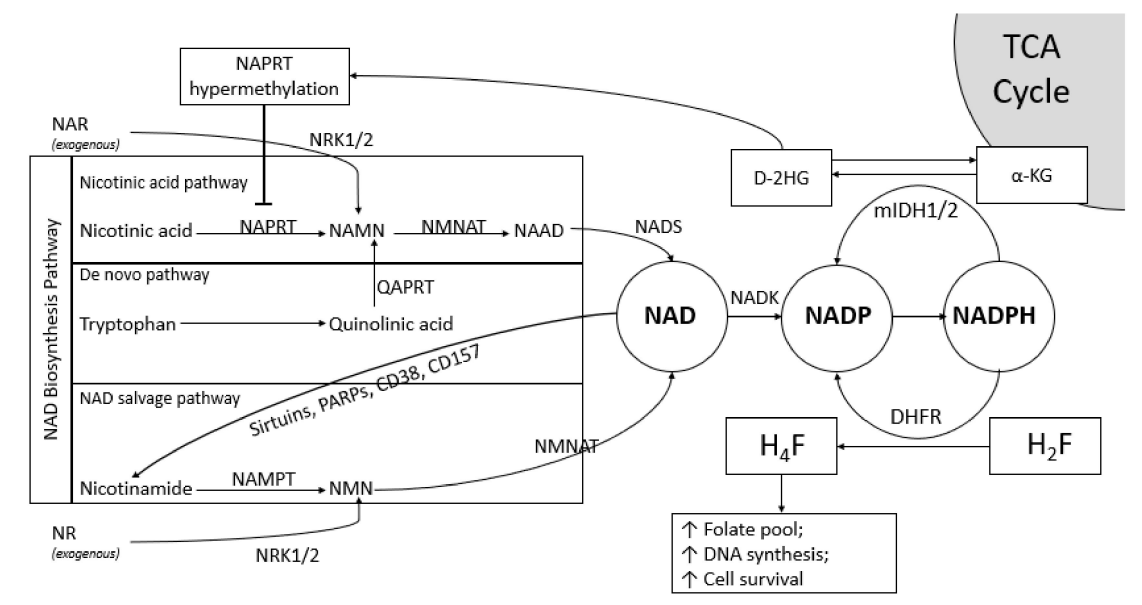

Figure 1. The association between IDH1/2 mutation and NAD Production in Cancer. Mutant IDH1/2 converts $\alpha$-ketoglutarate $(\alpha-\mathrm{KG})$ into D-2 hydroxyglutarate (D-2HG), an oncometabolite that causes hypermethylation at CPG islands of NAPRT promoter region, results in nicotinic acid pathway inhibition. Cancer cells maintain the adequate level of NAD pool through NAD salvage pathway and NADPH generation. NADPH is used as a substrate to generate $\mathrm{D}-2 \mathrm{HG}$ to promote oncogenesis. One of the possible mechanisms for cancer cell survival is achieved through catalytic activity of dihydrofolate reductase (DHFR) that maintains folate pool and induces DNA synthesis. TCA: tricarboxylic acid; NAPRT: nicotinate phosphoribosyltransferase; NAMN: nicotinic acid mononucleotide; NAAD: nicotinic acid adenine dinucleotide; NADS: NAD synthase; QAPRT: quinolinate phosphoribosyltransferase; NMN: nicotinamide mononucleotide; NAR: nicotinic acid riboside; NR: nicotinamide riboside; NRK1/2: nicotinamide riboside kinase 1/2; $\mathrm{H}_{2} \mathrm{~F}$ : dihydrofolate; $\mathrm{H}_{4} \mathrm{~F}$ : tetrahydrofolate.

\subsection{Therapeutic Role of NAMPT in Cancer}

NAMPT, a dimeric class of type II phosphoribosyltransferases, catalyzes NMN from Nam and 5'-phosphoribosyl-1-pyrophosphate (PRPP) [1]. NAMPT can be found in both intracellular and extracellular environments, including cytoplasm, blood, cerebrospinal fluids, adipose tissue, hepatic tissue, pancreatic tissue and almost every organ in the human body [1,47]. Phosphorylation at His247 increases the affinity of NAMPT to Nam and NAMPT enzymatic activity for more than 1000 folds $[1,48,49]$.

Increased serum concentrations of NAMPT have been linked with diseases such as obesity, non-alcoholic fatty liver disease, diabetes mellitus and in particular, cancers [35,36]. Colorectal cancer, ovarian cancer, breast cancer, prostate cancer, gastric cancer, melanoma and myeloma were found to overexpress NAMPT [15,44,50-53]. An increased NAD pool, as the consequence of NAMPT overexpression, was also associated with chemotherapeutic resistance [50,54]. Therefore, targeting NAMPT in tumors lacking NAPRT has been identified as an anti-cancer drug target. NAMPT knock-down has successfully sensitized cancer cells to increased ROS and cell death [44].

In vitro studies have shown promising results using a NAMPT inhibitor in cancer cells, especially the IDH1/2 mutant cancer cell lines (Table 1). MGG119, MGG152, BT142 primary glioblastoma cell lines; HT1080, 30T and SW1353 chondrosarcoma cell lines; SNU484, SNU668, SNU1750, MKN1 and Hs746T gastric cancer cell lines which have mutations in IDH1 [7-9], were sensitive to NAMPT inhibition. NAMPT inhibitors not only have shown promising effect as single-agent therapy, but were also found to sensitize other modalities of cancer treatment in both in vitro and in vivo experiments [45,55-57], as shown in Tables 2 and 3. 
Table 1. Performance of NAMPT inhibitors in NAPRT-deficient/depleted cancer cell lines.

\begin{tabular}{|c|c|c|c|c|c|c|}
\hline & Cell Lines & IDH Mutation & NAPRT Expression & $\begin{array}{c}\text { Sensitivity to } \\
\text { NAMPT Inhibitors }\end{array}$ & NAD & Refs. \\
\hline \multirow{3}{*}{ Glioblastoma } & MGG119 & $\mathrm{IDH}^{\mathrm{R} 132 \mathrm{H}}$ & Depleted & Highly sensitive & Decreased & \multirow{3}{*}[8,58]{} \\
\hline & MGG152 & $\mathrm{IDH}^{\mathrm{R} 132 \mathrm{H}}$ & Depleted & Highly sensitive & Decreased & \\
\hline & BT142 & $\mathrm{IDH}^{\mathrm{R} 132 \mathrm{H}}$ & ND & Highly sensitive & Decreased & \\
\hline \multirow{8}{*}{ Gastric cancer } & Hs746T & \multirow{8}{*}{ N/A } & Depleted & Highly sensitive & Decreased & \multirow{8}{*}{ [4] } \\
\hline & SNU1750 & & Depleted & Highly sensitive & $\mathrm{ND}$ & \\
\hline & MKN1 & & Depleted & Highly sensitive & ND & \\
\hline & SK4 & & Normal & Resistant & ND & \\
\hline & SNU484 & & Depleted & Highly sensitive & ND & \\
\hline & SNU668 & & Depleted & Highly sensitive & Decreased & \\
\hline & YCC11 & & Decreased & Moderately sensitive & ND & \\
\hline & GA077 & & Depleted & Highly sensitive & Decreased & \\
\hline Fibrosarcoma & HT1080 & $\mathrm{IDH}^{\mathrm{R} 132 \mathrm{C}}$ & Depleted & Highly sensitive & Decreased & {$[8,9,58,59]$} \\
\hline Melanoma & $30 \mathrm{~T}$ & $\mathrm{IDH}^{\mathrm{R} 132 \mathrm{C}}$ & ND & Highly sensitive & ND & {$[8]$} \\
\hline \multirow{10}{*}{ Chondrosarcoma } & SW1353 & $\mathrm{IDH} 2^{\mathrm{R} 122 \mathrm{~S}}$ & Depleted & Highly sensitive & \multirow{10}{*}{ ND } & \multirow{10}{*}[8,9]{} \\
\hline & JJ012 & IDH1R $^{132 G}$ & Depleted & Highly sensitive & & \\
\hline & L835 & $\mathrm{IDH}^{\mathrm{R} 132 \mathrm{C}}$ & Increased & Moderately sensitive & & \\
\hline & L2975 & $\mathrm{IDH} 2^{\mathrm{R} 132 \mathrm{~W}}$ & Depleted & Highly sensitive & & \\
\hline & $\mathrm{CH} 2879$ & IDH1/2 wt & Increased & Highly sensitive & & \\
\hline & NDCS-1 & IDH1/2 wt & Depleted & Highly sensitive & & \\
\hline & CH3573 & IDH1/2 wt & Decreased & Highly sensitive & & \\
\hline & L325b & IDH1/2 wt & Increased & Resistant & & \\
\hline & MCS170 & IDH1/2 wt & Decreased & Resistant & & \\
\hline & OUMS27 & IDH1/2 wt & Decreased & Moderately sensitive & & \\
\hline
\end{tabular}


Table 1. Cont

\begin{tabular}{ccccc}
\hline & Cell Lines & IDH Mutation & NAPRT Expression & $\begin{array}{c}\text { Sensitivity to } \\
\text { NAMPT Inhibitors }\end{array}$ \\
\hline \multirow{2}{*}{ Non-small cell lung cancer } & H460 & ND & Depleted & Highly sensitive \\
\cline { 2 - 5 } & A549 & ND & Decreased & Highly sensitive \\
\hline Multiple myeloma & H929 & ND & Depleted & Highly sensitive \\
\hline Glioblastoma & U251MG & ND & Depleted & Highly sensitive \\
\hline Pancreatic cancer & Mia-PaCa2 & ND & Depleted & Highly sensitive \\
\hline
\end{tabular}

Table 2. Performance of NAMPT inhibitor in combination in vitro.

\begin{tabular}{|c|c|c|c|}
\hline Cancer/Cell Lines & Drug Combination & Study Result & Refs. \\
\hline $\begin{array}{l}\text { Fibrosarcoma } \\
\text { HT1080 }\end{array}$ & $\begin{array}{l}2.5 \mathrm{nM} \text { FK-866/GMX-1778 + } 200 \mu \mathrm{M} \\
\text { Temozolomide }\end{array}$ & \multirow{2}{*}{$\begin{array}{l}\text { Decreased cell viability } \\
\text { Decreased NAD } \\
\text { Increased apoptosis } \\
\text { Increased ROS }\end{array}$} & \multirow{2}{*}[58,61]{} \\
\hline $\begin{array}{c}\text { Glioblastoma } \\
\text { MGG119, MGG152, BT142, U251 }\end{array}$ & 5/10 nM FK-866/CHS-828 + $100 \mu \mathrm{M}$ Temozolomide & & \\
\hline $\begin{array}{l}\text { Ewing Sarcoma } \\
\text { TC32, TC71 }\end{array}$ & 5 nM Daporinad (FK-866) + 5 nM Niraparib & $\begin{array}{l}\text { Decreased cell viability } \\
\text { Decreased NAD }\end{array}$ & [62] \\
\hline \multirow{3}{*}{$\begin{array}{l}\text { Pancreatic ductal adenocarcinoma } \\
\text { PaTu8988t, Panc-1 }\end{array}$} & 6.25 nM STF-118804 + 5 nM Gemcitabine & \multirow{3}{*}{ Decreased cell viability } & \multirow{3}{*}{ [45] } \\
\hline & 6.25 nM STF-118804 + 5 nM Paclitaxel & & \\
\hline & 6.25 nM STF-118804 + 300 nM Etoposide & & \\
\hline $\begin{array}{l}\text { Gastric cancer } \\
\text { BCG823 }\end{array}$ & $1 \mathrm{nM}$ FK-866 + 3 нg/mL 5-Fluorouracil & $\begin{array}{l}\text { Decreased cell viability } \\
\text { Increased apoptosis }\end{array}$ & [3] \\
\hline $\begin{array}{l}\text { Non-small cell lung cancer } \\
\text { A549, H1299 }\end{array}$ & $\begin{array}{l}150 \mathrm{nM} \text { Pemetrexed for } 48 \mathrm{~h}+8 \mathrm{nM} \text { GMX-1777 for } \\
\text { the next } 24 \mathrm{~h}\end{array}$ & $\begin{array}{c}\text { Decreased cell viability } \\
\text { Decreased ATP } \\
\text { Decreased NAD } \\
\text { Increased PARP expression }\end{array}$ & [60] \\
\hline
\end{tabular}


Table 2. Cont

\begin{tabular}{|c|c|c|c|}
\hline Cancer/Cell Lines & Drug Combination & Study Result & Refs. \\
\hline $\begin{array}{c}\text { Triple-negative breast cancer } \\
\text { CAL51 }\end{array}$ & 10/100 nM FK866 + 0.1/1/10 $\mu$ M Olaparib & $\begin{array}{l}\text { Decreased cell viability } \\
\text { Decreased NAD } \\
\text { Increased apoptosis }\end{array}$ & [63] \\
\hline $\begin{array}{l}\text { Leukemia } \\
\text { MV4-11 }\end{array}$ & 100 nM KPT-9274 + 10 nM Venetoclax & $\begin{array}{l}\text { Decreased cell viability } \\
\text { Decreased NAD }\end{array}$ & {$[64]$} \\
\hline $\begin{array}{c}\text { Jurkat } \\
\text { MOLT-4 }\end{array}$ & 10 nM FK-866 + 5/10 $\mu$ M Etoposide & $\begin{array}{c}\text { Decreased cell viability } \\
\text { Decreased PARP-1 expression } \\
\text { Increased apoptosis }\end{array}$ & [65] \\
\hline $\begin{array}{c}\text { OCI/AML3, Mec.1 } \\
\text { LAMA-84, RPMI-8226 }\end{array}$ & $\begin{array}{l}3 \mathrm{nM} \text { APO866 for } 48 \mathrm{~h}+10 \mu \mathrm{M} \text { verapamil/ } 1 \mu \mathrm{M} \\
\text { Cyclosporin A/10 } \mu \mathrm{M} \text { PGP-4008 for the next } 48 \mathrm{~h} \\
3 \mathrm{nM} \text { APO866 for } 48 \mathrm{~h}+1 \mu \mathrm{M} \text { Cyclosporin A for } \\
\text { the next } 48 \mathrm{~h}\end{array}$ & $\begin{array}{l}\text { Decreased cell viability } \\
\text { Increased apoptosis }\end{array}$ & {$[66]$} \\
\hline $\begin{array}{c}\text { Leukemia } \\
\text { Jurkat, PEER, H9, Namalwa }\end{array}$ & 0.1/3.2/4 nM APO866 + 0.1/6.3/100 ng/mL TRAIL & $\begin{array}{l}\text { Decreased cell viability } \\
\text { Decreased ATP } \\
\text { Decreased NAD } \\
\text { Increased cell death } \\
\text { Increased autophagy }\end{array}$ & [67] \\
\hline $\begin{array}{c}\text { Multiple myeloma } \\
\text { RPMI-8226/S, U266, MM1S, MM1R, ANBL6 }\end{array}$ & $1 \mathrm{nM} / 3 \mathrm{nM}$ FK-866 + $5 \mathrm{nM} / 10 \mathrm{nM}$ Bortezomib & $\begin{array}{l}\text { Decreased cell viability } \\
\text { Decreased NAD } \\
\text { Increased apoptosis }\end{array}$ & [68] \\
\hline $\begin{array}{l}\text { Waldenström macroglobulinemia } \\
\text { BCMW.1, MWCL.1 }\end{array}$ & 3 nM FK-866 + $1 \mu$ M Ibrutinib & $\begin{array}{c}\text { Decreased cell viability } \\
\text { Decreased ATP } \\
\text { Decreased NAD } \\
\text { Increased apoptosis }\end{array}$ & {$[64,69]$} \\
\hline
\end{tabular}


Table 3. Performance of NAMPT inhibitor in combination in vivo.

\begin{tabular}{|c|c|c|c|}
\hline Cancer/Cell Lines & Drug Combinations & Study Result & Refs. \\
\hline $\begin{array}{l}\text { Non-small cell lung cancer } \\
\text { A549, H1299 }\end{array}$ & $\begin{array}{c}150 \mathrm{mg} / \mathrm{kg} / \text { day GMX-1777 for } 5 \text { days, i.m. }+600 \mathrm{mg} / \mathrm{kg} / \mathrm{day} \\
\text { Pemetrexed for } 5 \text { days, i.p. }\end{array}$ & $\begin{array}{l}\text { Decreased tumor volume } \\
\text { Increased body weight }\end{array}$ & {$[60]$} \\
\hline $\begin{array}{l}\text { Ewing Sarcoma } \\
\text { TC32, TC71 }\end{array}$ & 25 mg/kg GNE-618 p.o. +50 mg/kg Niraparib p.o. & $\begin{array}{l}\text { Decreased tumor volume } \\
\text { Increased survival }\end{array}$ & [62] \\
\hline $\begin{array}{l}\text { Neuroendocrine tumor } \\
\text { GOT1 }\end{array}$ & $\begin{array}{l}100 \text { mg/kg GMX-1778, three weekly doses, p.o. + } 7.5 \text { MBq } \\
\text { 177Lu-DOTATATE, single dose, i.v. }\end{array}$ & $\begin{array}{l}\text { Decreased tumor volume } \\
\text { Increased survival }\end{array}$ & [70] \\
\hline $\begin{array}{l}\text { Prostate cancer } \\
\text { PC3 }\end{array}$ & $\begin{array}{c}4 \text { injections } 10 \mathrm{mg} / \mathrm{kg} \text { of APO- } 866 \text { for } 2 \text { days }+4 \text { fractions } \\
3 \mathrm{~Gy} \text { radiation for } 4 \text { days }\end{array}$ & $\begin{array}{l}\text { Delayed tumor growth } \\
\text { Increased survival }\end{array}$ & [71] \\
\hline $\begin{array}{c}\text { Triple-negative breast cancer } \\
\text { CAL51 }\end{array}$ & $\begin{array}{l}6 \mathrm{mg} / \mathrm{kg} \text { FK } 866+15 \mathrm{mg} / \mathrm{kg} \text { Olaparib for } 5 \text { days, followed by } \\
2 \text { days of no treatment, maintained upon study completion }\end{array}$ & $\begin{array}{l}\text { Decreased tumor volume } \\
\text { Increased body weight }\end{array}$ & [63] \\
\hline $\begin{array}{l}\text { Ovarian cancer } \\
\text { OVCAR-3 }\end{array}$ & $\begin{array}{c}10 \mathrm{mg} / \mathrm{kg} / \text { day FK866, i.p. }+15 \mathrm{mg} / \mathrm{kg} \mathrm{APCP,} \mathrm{i.p.,} \mathrm{every} \\
\text { other two days for } 28 \text { days }\end{array}$ & $\begin{array}{c}\text { Reduced NAD, NMN, ATP } \\
\text { Increased cancer necrotic area (Ki67 }{ }^{+} \text {staining) } \\
\text { Increased survival }\end{array}$ & {$[72]$} \\
\hline \multirow{2}{*}{$\begin{array}{l}\text { Waldenström macroglobulinemia } \\
\text { BCMW.1 }\end{array}$} & $\begin{array}{l}30 \mathrm{mg} / \mathrm{kg} / \text { day FK } 866 \text { for } 4 \text { days in a week (with } 3 \text { days off), } \\
\text { repeated for } 3 \text { weeks }+0.5 \mathrm{mg} / \mathrm{kg} / \text { day Ibrutinib for } 5 \text { days, } \\
\text { repeated for } 3 \text { weeks }\end{array}$ & $\begin{array}{l}\text { Decreased tumor volume } \\
\text { Increased survival }\end{array}$ & [69] \\
\hline & $\begin{array}{c}100 \mathrm{mg} / \mathrm{kg} / \text { day KPT-9274 for } 5 \text { consecutive days/week for } \\
3 \text { weeks }+25 \mathrm{mg} / \mathrm{kg} \text { Bendamustine, one single dose/week } \\
\text { for } 2 \text { consecutive weeks }\end{array}$ & $\begin{array}{c}\text { Highly sensitive } \\
\text { Increased apoptosis } \\
\text { Decreased tumor volume }\end{array}$ & {$[64]$} \\
\hline $\begin{array}{l}\text { Multiple myeloma } \\
\text { MM1S }\end{array}$ & $\begin{array}{l}30 \mathrm{mg} / \mathrm{kg} \text { FK-866 for } 4 \text { days repeated weekly for } 3 \text { weeks, } \\
\text { i.p. }+0.5 \mathrm{mg} / \mathrm{kg} \text { Bortezomib biweekly for } 3 \text { weeks, s.c. }\end{array}$ & $\begin{array}{l}\text { Decreased tumor volume } \\
\text { Increased survival }\end{array}$ & {$[68]$} \\
\hline
\end{tabular}

i.m.: intramuscular; i.p.: intraperitoneal; p.o.: peroral; i.v.: intravenous; s.c.: subcutaneous. 
As preclinical studies with NAMPT showed encouraging results [73-75], the clinical efficacy and safety of NAMPT inhibitors has been tested in cancer patients. There are 8 registered trials for NAMPT inhibitors in cancers in clinicaltrials.gov. The first registered NAMPT inhibitor trial in humans (NCT00003979) was initiated in 1999 and withdrawn in 2012. Some of the earliest trials of NAMPT inhibitor were phase I studies utilizing the NAMPT inhibitor CHS828, to treat solid tumors. They established the recommended dose for CHS828; however, studies were not recommended for further trials due to disease progression and severe adverse events experienced by study subjects [76-78]. A phase II clinical trial utilizing the NAMPT inhibitor, FK866 for cutaneous T-cell lymphoma was terminated due to failure to achieve remissions and serious adverse events [79]. Disappointing results were attributed to cellular uptake of extracellular NAD precursors such as vitamin B3, nicotinic acid riboside and dietary tryptophan [80]. In these studies patients were not selected for IDH mutations. Importantly, D-2HG accumulation and NAPRT hypermethylation that occurs in mutant IDH1/2 cancers could be potential candidates for NAMPT inhibitor trials as they lack NA pathway (Figure 1).

\subsection{Mutant Isocitrate Dehydrogenases Inhibit NAD Production in Cancer}

Isocitrate dehydrogenase (IDH) converts isocitrate into $\alpha$-ketoglutarate $(\alpha-\mathrm{KG})$ in the TCA cycle with $\mathrm{NADP}^{+}$as its cofactor. IDH exists in three isozymes, namely IDH1, IDH2 and IDH3. IDH1, located in the cytosol and peroxisome, is encoded by the IDH1 gene on chromosome 2q34, while IDH2 is localized in the mitochondria and is encoded by the gene located on chromosome 15q26.1 [41]. Both enzymes are NADP-dependent, share high degree of homology and conduct a reversible reaction to maintain the isocitrate pool [12]. Unlike the other two isozymes, IDH3, localized in the mitochondria, exists as a heterocomplex enzyme consisting of $\alpha, \beta$, and $\gamma$ subunits that are encoded by IDH3A (15q25.1), IDH3B (20p13), and IDH3C (Xq28) genes, respectively [41]. IDH3 is activated by adenosine diphosphate (ADP) and inhibited by adenosine triphosphate (ATP). In order to ensure the continuity of TCA cycle, IDH3 conducts the irreversible conversion of isocitrate to maintain the $\alpha-K G$ pool $[12,41,81]$.

IDH mutations have been associated with several cancers, in particular, WHO grade II/III and secondary glioblastoma multiforme (GBM), acute myeloid leukemia (AML), intrahepatic cholangiocarcinoma, gastric cancer and cartilaginous tumors [9,82-85]. Most of mutant IDH1 tumors have a single, missense mutation at codon 132 that changes arginine to histidine (IDH1 $\left.{ }^{\mathrm{R} 132 \mathrm{H}}\right)$. The other base substitution with arginine and other amino acid residue at the same position has also been reported $[12,13,81]$. Similarly, the most frequent hot spots for mutant $I D H 2$ tumors are arginine at other positions, R172K and R140Q. The accumulation of NADPH derived from isocitrate conversion to $\alpha-K G$ is used to maintain the pool of reduced glutathione (GSH), peroxiredoxin and catalase tetramers that scavenge ROS [12,41]. NADPH may benefit mutant IDH cancers as it assists mutant IDH in generating D-2HG from $\alpha$-KG to promote oncogenesis [37,50].

Mutant IDH1/2 utilizes NADPH to convert $\alpha-K G$ to D-2HG and NADP. Physiologically, D-2HG is produced in a very small amounts as a result of errors in metabolism [12]. Thus, the mutant IDH1/2 displays a new ability to convert $\alpha$-KG to D-2HG. D-2HG competitively binds dioxygenases, including the ten-eleven translocation (TET) family of 5-methylcytosine hydroxylases, the Jumonji-domain containing histone-lysine demethylases (JMJ-KDMs), the AlkB family of dioxygenases, the hypoxia-inducible factor (HIF) prolyl 4-hydroxylases and asparaginyl hydroxylase, and the collagen prolyl and lysine hydroxylases. D-2HG modulates epigenetic regulation and increases the chance of tumorigenesis in mutant IDH1/2 cells [12,41].

D-2HG inhibits the $\alpha$-KG dependent dioxygenases, TET2 and JMJD-KDMs causing hypermethylation in the mutant IDH1/2 tumors [81]. One of the causes of tumorigenesis is chromatin modification in mutant IDH tumors. TET2, a tumor suppressor gene as well as a part of the TET family, is usually mutated and causes hypermethylation in AML cancers. Hypermethylation was observed at CCCTC-binding factor (CTCF)-binding sites, insulator sequences that block the interaction between enhancers and promoters, causing chromatin modifications to modulate the gene expression in the tumorigenesis process $[12,13,41,81]$. 


\section{Targeting NADPH Formation}

\subsection{Therapeutic Role of NAD Kinase}

Cancer cells depend on the availability of NADPH to provide defense against reactive oxygen species (ROS) that is generated from cancer proliferating activity [86]. The formation of NADPH is catalyzed by NAD Kinase (NADK) and dehydrogenases which convert NAD to NADP and NADP to NADPH, respectively [87]. NADK was discovered by Kornberg in 1950 after Vestin, von Euler and Adler observed NADP formation in yeast [87]. Since then, NADK has been found in algae, high-level plants, and animals, including monkey, rabbit, chicken liver and ground squirrels [87-89]. NADK was found in almost all human organs except skeletal muscle. It is localized in the cytoplasm and recently a mitochondrial enzyme has been described [90-93]. The cytoplasmic enzyme consists of four subunit polypeptides and optimally works at temperature of $55^{\circ} \mathrm{C}$ and $\mathrm{pH} 7.5[90,91]$. NADK requires NAD and ATP and a divalent metal ion such as zinc, manganese and magnesium [90]. NADK has also been observed to play a role in physiology and pathophysiology of diseases, including cancers [92,94-96]. NADK generates NADPH that is important to scavenge ROS, and promote cell longevity $[97,98]$. Thus, targeting NADK in cancer has been recognized as another potential anti-cancer target [10].

NADK is inhibited by thionicotinamide adenine dinucleotide (NADS) and thionicotinamide adenine dinucleotide phosphate (NADPS) $[10,11,86]$. The prodrug thionicotinamide, $(\mathrm{TN})$ is converted into NADS and NADPS intracellularly and acts as dual inhibitor of NADK and glucose-6-phosphate dehydrogenase (G6PD) that catalyzes NADPH production. Reducing intracellular NADPH results in an increase in ROS $[10,11]$. Reduction of $\mathrm{NADP}^{+}$by dehydrogenases produces NADPH the substrate for glutathione reductase and mediates the production 5-phosphoribosyl-1-pyrophosphate (PRPP), the substrate for the synthesis of purine and pyrimidine. Depletion of NADPH puts cancer cells in higher oxidative state and limits availability of nucleic acid for DNA replication.

TN successfully delayed tumor growth in xenograft mouse models of colon cancer and diffuse large B cell lymphoma (DLBCL) and in vitro synergized with other ROS-inducing chemotherapeutic agents [10]. As mutant IDH requires NADPH to produce D-2HG, thus, a NADK inhibitor might be a novel therapeutic approach for treating mutant IDH cancer cells to decrease the NADPH pool which may not be sufficient to facilitate the production of the D-2HG oncometabolite.

\subsection{NADPH Stabilizes Dihydrofolate Reductase (DHFR)}

DHFR catalyzes the reduction of folic acid and dihydrofolate $\left(\mathrm{H}_{2} \mathrm{~F}\right)$ to tetrahydrofolate $\left(\mathrm{H}_{4} \mathrm{~F}\right)$, utilizing NADPH as a cofactor and is important enzyme for de-novo- purine and thymidine biosynthesis [99]. The discovery of methotrexate as a competitive inhibitor of DHFR opened many avenues for cancer therapeutic purposes [100]. To understand the mechanism of methotrexate resistance in cancers or up-regulation of DHFR in such cancers, it became evident that the interaction of DHFR with its co-factor NADPH plays a key role to regulate its interaction as well as its expression [11,101].

DHFR exists in two interconvertible conformers, one binding to its mRNA and regulates its translation and other conformer binds to NADPH to regulate its function as well [99]. The binding of methotrexate to DHFR-NADPH conformer leads to inhibition of its catalytic function, however binding to other conformer was found to shift the chemical equilibrium towards releasing the DHFR from its own mRNA and thus resulting in DHFR translation. Different studies $[101,102]$ supported that the NADPH binding domain regulates DHFR translation. DHFR mutants (both catalytic or NADPH binding) alter its binding with its substrate or co-factors and modify its regulation $[99,101]$. Recently our group showed that targeting NADK by TN caused a decrease of NADPH which destabilized DHFR and caused its degradation [10,11]. Thus, lowering levels of DHFR may play a role in the anticancer activity of TN $[10,11,99,103]$. Targeting the NADPH pool via DHFR inhibition opens another window in cancer therapeutics. 


\subsection{Methylenetetrahydrofolate Dehydrogenase (MTHFD) Maintains NADP/NADPH Pools in Cancer}

MTHFD2 is an enzyme that is required for tumor cell survival [104]. MTHFD2 is highly expressed in the mitochondria and nucleus of multiple types of tumor cells, but not in non-transformed cells [104]. The only non-transformed cell induction of MTHFD2 was observed in lymphocyte activation, indicating the role of MTHFD2 in normal hematopoietic cells as well as in the tumorigenesis process of hematologic malignancies [105].

MTHFD2 plays a significant role in the mitochondrial folate-dependent one carbon (1C) metabolism by oxidizing the $1 \mathrm{C}$ unit and recycling folate cofactor needed by the enzyme serine hydroxymethyltransferase 2 (SHMT2) [104,105]. Both reactions are highly important to ensure rapid cancer proliferation [104,105]. MTHFD2 exists as two isozymes, MTHFD2 and MTHFD2L. Both isozymes are bifunctional enzymes that are responsible for the NAD-dependent $\mathrm{CH}_{2}-\mathrm{THF}$ dehydrogenase and $\mathrm{CH}^{+}$-THF cyclohydrolase reactions within the mitochondria. The cytosolic counterpart, MTHFD1 is a trifunctional enzyme having dehydrogenase, cyclohydrolase and formyltetrahydrofolate synthetase activities. Recently another isozyme MTHFD1L, another mitochondrial enzyme was stuided in colorectal and bladder cancers, is a monofunctional enzyme that catalyses the formation of formate and THF cofactor regeneration. MTHFD1L enhanced proliferation in some cancer tissues, as knock down of MTHFD1L slowed the tumor growth [106,107].

The reactions catalysed by MTHFD2 and its isozyme are NAD-dependent [108]. MTHFD2 is critical in maintaining NADP/NADPH production as it showed specific redox cofactor activity with NAD and NADP [108,109]. Suppression of MTHFD2 disturbed NADPH pools and enhanced apoptosis due to accumulated oxidative stress [110]. Therefore, NAD depletion might also interfere with folate metabolism and cause cancer cell death.

\subsection{Serine Hydroxymethyltransferase (SHMT) Maintains NADP/NADPH Pools in Cancer}

SHMT2 is a mitochondrial enzyme that converts serine into glycine simultaneously converting tetrahydrofolate to 5,10-methylene- $\mathrm{H}_{4} \mathrm{~F}$ [105,111]. SHMT2 plays an important role in folate metabolism as serine is a dominant source of $1 \mathrm{C}$ unit [111]. Increased regulation of mitochondrial $1 \mathrm{C}$ elevates the production of $1 \mathrm{C}$ unit, biosynthesis of adenosine, guanosine, thymidylate and remethylation of homocystein to support methionine cycle [111,112]. The accumulated 1C units are important to support folate metabolism which regenerates the redox cofactors NADPH, NADH and ATP [112].

Overexpression of SHMT2 has been found in cancers and associated with poor prognosis in cancer patients [111,113]. However, it is not sufficient to cause malignant transformation alone [114]. Increased expression in mRNA and protein of SHMT2 was found in hepatocellular carcinoma cell lines. Downregulating SHMT2, either by shRNA knock down, SHMT2 silencing, or inhibition using L-mimosine, suppressed tumor growth and increased chemotherapeutic sensitivity [114,115]. SHMT2 knockdown leads to decreased NADPH and impaired cancer survival [116]. Impairment of folate metabolism will decrease the production of NADPH, NADH, ATP and further cause cell death [112]. Therefore, SHMT2 is a potential target in cancer therapeutics. Targeting SHMT2 disturbs the homeostasis of NADP/NADPH pool which is important in cancer survival.

\subsection{Targeting Aldehyde Dehydrogenase (ALDH) Sensitizes Cancer}

Aldehyde dehydrogenases are groups of NAD-dependent enzymes in the ALDH superfamily that consists of 19 different NADP-dependent ALDH enzymes. ALDHs are localized in both cytosol and mitochondria [117]. Crystallographic analysis has shown that ALDH has a specific coenzyme NAD binding domain. This implies that NAD is a significant component required by ALDH to execute its functions in retinoic acid biosynthesis, GABA neurotransmitter metabolism and alcohol metabolism [117].

ALDH1A3, a member of ALDH1A subfamily, is associated with cancer incidence, progression, prognosis and chemotherapeutic resistance [117-119]. The gene encoding ALDH1A3 consists of 
16 exons and is located on chromosome 15q26.3. It is localized in the cytoplasm, nucleus and mitochondria [119,120]. This enzyme converts all-trans-retinal into retinoic acid [119,121,122]. ALDH catalytic reactions produce vast amount of cytosolic NADH as the source of ATP generation in cancers [123]. ALDH1A3 also plays a role in generating acetic acid from acetaldehyde in glycolysis and gluconeogenesis as well as metabolizing amino acids, exogenous chemical substances via cytochrome P450 and lipid peroxidase product $[119,121]$. ALDH1A3 catalyzes peroxidation, a process that produces fatty aldehyde, an intermediate compound in producing fatty acid and NADPH [119,124]. ALDH1A3 indirectly regulates apoptosis through retinoic acid pathway by increasing expression of caspase-7 and caspase-9 $[119,125]$.

ALDH1A3 is also expressed in some cancers, including pancreatic cancer, ovarian cancer and high-grade gliomas [119,126-128]. Hypermethylation of ALDH1A3 promoter region was found to be one of the underlying mechanisms in some cancers [129-132]. Overexpressing ALDH1A3 is associated with cancer stem cell characteristics by increasing cancer cell proliferation. ALDH1A3 knockdown decreased tumorigenesis [119,133-135]. An increased level of ALDH1A3 also correlates with chemotherapeutic resistance [119]. Therefore, targeting ALDH1A3 in cancer is of great interest.

Inhibition of ALDH cause ATP depletion that inhibits tumor growth in both in vitro and xenograft models $[124,132]$. Knockdown of ALDH significantly decreased NADH and ATP production in cancer [124,136]. Downregulation of ALDH1A3 sensitized cancer cells, prolonged G1 phase, shortened $S$ phase and decreased cancer cell survival both in vitro and in vivo $[135,137]$. ALDH1A3 is a prominent target for chemotherapy in cancer as its inhibition disrupts NADH and ATP pools, shuts the power factory off in cancer, and sensitizes cancer cell death.

\section{Conclusions}

Exploring NAD biogenesis for cancer therapeutics had been studied for decades [24,25,35,91,92,94]. The NAD pool in cells is contributed by the simultaneous functioning of various pathways as mentioned in this review, viz-a-viz, NA pathway, de novo pathway and NAD salvage pathway. The malfunctioning of the enzymes in any of these pathways may alter the NAD pool of cells. Cancer cells attempt to maintain the NAD pool. In some cancers, the rate limiting enzyme of one of the NAD biogenesis pathways may be over expressed or a mutation in one pathway may alter the turn-over of the other pathway to sustain the NAD pool. Different metabolic enzymes including NAMPT, NAPRT, IDH, NADK, DHFR, MTHFD, SHMT and ALDH, are dysregulated in various cancer types, making them potential anti-cancer targets. Mutations in some NAD and NADPH metabolic enzymes cause epigenetic regulation and affect expression of different genes involved in different cellular processes. Thus, targeting different rate limiting enzymes alone or in combination opens many therapeutic opportunities to treat cancers.

Author Contributions: Conceptualization, A.A.P., G.M.R., and J.R.B..; data curation, A.A.P. and G.M.R.; writing-original draft preparation, A.A.P.; writing—review and editing, A.A.P., G.M.R., H.H., K.L., and J.R.B. All authors have read and agreed to the published version of the manuscript.

Acknowledgments: We thank Tri Hanggono Achmad, Arief Kartasasmita, Ramdan Panigoro, Ajeng Diantini, Rizky Abdulah and Aliya Nur Hasanah from Universitas Padjadjaran, Indonesia; Debabrata Banerjee, Zoltan Szekely, Sharon R. Pine and Shashi Sharma from Rutgers Cancer Institute of New Jersey, Rutgers, The State University of New Jersey for providing constructive discussions.

Conflicts of Interest: The authors declare no conflict of interest.

\section{References}

1. Garten, A.; Schuster, S.; Penke, M.; Gorski, T.; de Giorgis, T.; Kiess, W. Physiological and pathophysiological roles of NAMPT and NAD metabolism. Nat. Rev. Endocrinol. 2015, 11, 535-546. [CrossRef] [PubMed]

2. Zhu, Y.; Liu, J.; Park, J.; Rai, P.; Zhai, R.G. Subcellular compartmentalization of NAD(+) and its role in cancer: A sereNADe of metabolic melodies. Pharmacol. Ther. 2019, 200, 27-41. [CrossRef] [PubMed] 
3. Bi, T.Q.; Che, X.M.; Liao, X.H.; Zhang, D.J.; Long, H.L.; Li, H.J.; Zhao, W. Overexpression of Nampt in gastric cancer and chemopotentiating effects of the Nampt inhibitor FK866 in combination with fluorouracil. Oncol. Rep. 2011, 26, 1251-1257. [PubMed]

4. Audrito, V.; Manago, A.; Gaudino, F.; Sorci, L.; Messana, V.G.; Raffaelli, N.; Deaglio, S. NAD-Biosynthetic and Consuming Enzymes as Central Players of Metabolic Regulation of Innate and Adaptive Immune Response in Cancer. Front. Immunol. 2019, 10, 1720. [CrossRef] [PubMed]

5. Heske, C.M. Beyond Energy Metabolism: Exploiting the Additional Roles of NAMPT for Cancer Therapy. Front. Oncol. 2019, 9, 1514. [CrossRef]

6. Chiarugi, A.; Dolle, C.; Felici, R.; Ziegler, M. The NAD metabolome-a key determinant of cancer cell biology. Nat. Rev. Cancer 2012, 12, 741-752. [CrossRef]

7. Lee, J.; Kim, H.; Lee, J.E.; Shin, S.J.; Oh, S.; Kwon, G.; Kim, H.; Choi, Y.Y.; White, M.A.; Paik, S.; et al. Selective Cytotoxicity of the NAMPT Inhibitor FK866 Toward Gastric Cancer Cells With Markers of the Epithelial-Mesenchymal Transition, Due to Loss of NAPRT. Gastroenterology 2018, 155, 799-814.e13. [CrossRef]

8. Tateishi, K.; Wakimoto, H.; Iafrate, A.J.; Tanaka, S.; Loebel, F.; Lelic, N.; Wiederschain, D.; Bedel, O.; Deng, G.; Zhang, B.; et al. Extreme Vulnerability of IDH1 Mutant Cancers to NAD+ Depletion. Cancer Cell 2015, 28, 773-784. [CrossRef]

9. Peterse, E.F.P.; van den Akker, B.; Niessen, B.; Oosting, J.; Suijker, J.; de Jong, Y.; Danen, E.H.J.; Cleton-Jansen, A.M.; Bovée, J.V.M.G. NAD Synthesis Pathway Interference Is a Viable Therapeutic Strategy for Chondrosarcoma. Mol. Cancer Res. 2017, 15, 1714-1721. [CrossRef]

10. Tedeschi, P.M.; Lin, H.; Gounder, M.; Kerrigan, J.E.; Abali, E.E.; Scotto, K.; Bertino, J.R. Suppression of Cytosolic NADPH Pool by Thionicotinamide Increases Oxidative Stress and Synergizes with Chemotherapy. Mol. Pharmacol. 2015, 88, 720-727. [CrossRef]

11. Hsieh, Y.C.; Tedeschi, P.; Adebisi Lawal, R.; Banerjee, D.; Scotto, K.; Kerrigan, J.E.; Lee, K.C.; Johnson-Farley, N.; Bertino, J.R.; Abali, E.E. Enhanced degradation of dihydrofolate reductase through inhibition of NAD kinase by nicotinamide analogs. Mol. Pharmacol. 2013, 83, 339-353. [CrossRef] [PubMed]

12. Dang, L.; Su, S.M. Isocitrate Dehydrogenase Mutation and (R)-2-Hydroxyglutarate: From Basic Discovery to Therapeutics Development. Annu. Rev. Biochem. 2017, 86, 305-331. [CrossRef] [PubMed]

13. Clark, O.; Yen, K.; Mellinghoff, I.K. Molecular Pathways: Isocitrate Dehydrogenase Mutations in Cancer. Clin. Cancer Res. 2016, 22, 1837-1842. [CrossRef] [PubMed]

14. Warburg, O. On respiratory impairment in cancer cells. Science 1956, 124, 269-270.

15. Vaupel, P.; Schmidberger, H.; Mayer, A. The Warburg effect: Essential part of metabolic reprogramming and central contributor to cancer progression. Int. J. Radiat. Biol. 2019, 95, 912-919. [CrossRef]

16. Pavlova, N.N.; Thompson, C.B. The Emerging Hallmarks of Cancer Metabolism. Cell Metab. 2016, 23 , $27-47$. [CrossRef]

17. Ashton, T.M.; McKenna, W.G.; Kunz-Schughart, L.A.; Higgins, G.S. Oxidative Phosphorylation as an Emerging Target in Cancer Therapy. Clin. Cancer Res. 2018, 24, 2482-2490. [CrossRef]

18. Whitaker-Menezes, D.; Martinez-Outschoorn, U.E.; Flomenberg, N.; Birbe, R.C.; Witkiewicz, A.K.; Howell, A.; Pavlides, S.; Tsirigos, A.; Ertel, A.; Pestell, R.G.; et al. Hyperactivation of oxidative mitochondrial metabolism in epithelial cancer cells in situ: Visualizing the therapeutic effects of metformin in tumor tissue. Cell Cycle 2011, 10, 4047-4064. [CrossRef]

19. Jones, R.A.; Robinson, T.J.; Liu, J.C.; Shrestha, M.; Voisin, V.; Ju, Y.; Chung, P.E.; Pellecchia, G.; Fell, V.L.; Bae, S.; et al. RB1 deficiency in triple-negative breast cancer induces mitochondrial protein translation. J. Clin. Investig. 2016, 126, 3739-3757. [CrossRef]

20. Birkenmeier, K.; Drose, S.; Wittig, I.; Winkelmann, R.; Kafer, V.; Doring, C.; Hartmann, S.; Wenz, T.; Reichert, A.S.; Brandt, U.; et al. Hodgkin and Reed-Sternberg cells of classical Hodgkin lymphoma are highly dependent on oxidative phosphorylation. Int. J. Cancer 2016, 138, 2231-2246. [CrossRef]

21. Zacksenhaus, E.; Shrestha, M.; Liu, J.C.; Vorobieva, I.; Chung, P.E.D.; Ju, Y.; Nir, U.; Jiang, Z. Mitochondrial OXPHOS Induced by RB1 Deficiency in Breast Cancer: Implications for Anabolic Metabolism, Stemness, and Metastasis. Trends Cancer 2017, 3, 768-779. [CrossRef] [PubMed]

22. Tan, A.S.; Baty, J.W.; Dong, L.F.; Bezawork-Geleta, A.; Endaya, B.; Goodwin, J.; Bajzikova, M.; Kovarova, J.; Peterka, M.; Yan, B.; et al. Mitochondrial genome acquisition restores respiratory function and tumorigenic potential of cancer cells without mitochondrial DNA. Cell Metab. 2015, 21, 81-94. [CrossRef] [PubMed] 
23. Kulikova, V.A.; Gromyko, D.V.; Nikiforov, A.A. The Regulatory Role of NAD in Human and Animal Cells. Biochemistry Mosc. 2018, 83, 800-812. [CrossRef] [PubMed]

24. Preiss, J.; Handler, P. Biosynthesis of diphosphopyridine nucleotide. I. Identification of intermediates. J. Biol. Chem. 1958, 233, 488-492. [PubMed]

25. Preiss, J.; Handler, P. Biosynthesis of diphosphopyridine nucleotide. II. Enzymatic aspects. J. Biol. Chem. 1958, 233, 493-500.

26. Yaku, K.; Okabe, K.; Hikosaka, K.; Nakagawa, T. NAD Metabolism in Cancer Therapeutics. Front. Oncol. 2018, 8, 622. [CrossRef]

27. Bieganowski, P.; Brenner, C. Discoveries of nicotinamide riboside as a nutrient and conserved NRK genes establish a Preiss-Handler independent route to NAD+ in fungi and humans. Cell 2004, 117, 495-502. [CrossRef]

28. Fletcher, R.S.; Lavery, G.G. The emergence of the nicotinamide riboside kinases in the regulation of NAD+ metabolism. J. Mol. Endocrinol. 2018, 61, R107-R121. [CrossRef]

29. Tempel, W.; Rabeh, W.M.; Bogan, K.L.; Belenky, P.; Wojcik, M.; Seidle, H.F.; Nedyalkova, L.; Yang, T.; Sauve, A.A.; Park, H.W.; et al. Nicotinamide riboside kinase structures reveal new pathways to NAD+. PLoS Biol. 2007, 5, e263. [CrossRef]

30. Kulikova, V.; Shabalin, K.; Nerinovski, K.; Dolle, C.; Niere, M.; Yakimov, A.; Redpath, P.; Khodorkovskiy, M.; Migaud, M.E.; Ziegler, M.; et al. Generation, Release, and Uptake of the NAD Precursor Nicotinic Acid Riboside by Human Cells. J. Biol. Chem. 2015, 290, 27124-27137. [CrossRef]

31. Poljsak, B. NAD+ in cancer prevention and treatment: Pros and cons. J. Clin. Exp. Oncol. 2016, 5, 1-15. [CrossRef]

32. Shah, G.M.; Shah, R.G.; Veillette, H.; Kirkland, J.B.; Pasieka, J.L.; Warner, R.R. Biochemical assessment of niacin deficiency among carcinoid cancer patients. Am. J. Gastroenterol. 2005, 100, 2307-2314. [CrossRef] [PubMed]

33. Clement, D.S.; Tesselaar, M.E.; van Leerdam, M.E.; Srirajaskanthan, R.; Ramage, J.K. Nutritional and vitamin status in patients with neuroendocrine neoplasms. World J. Gastroenterol. 2019, 25, 1171-1184. [CrossRef] [PubMed]

34. Bouma, G.; van Faassen, M.; Kats-Ugurlu, G.; de Vries, E.G.; Kema, I.P.; Walenkamp, A.M. Niacin (Vitamin B3) Supplementation in Patients with Serotonin-Producing Neuroendocrine Tumor. Neuroendocrinology 2016, 103, 489-494. [CrossRef]

35. Kirkland, J.B. Niacin and carcinogenesis. Nutr. Cancer 2003, 46, 110-118. [CrossRef]

36. Park, S.M.; Li, T.; Wu, S.; Li, W.Q.; Weinstock, M.; Qureshi, A.A.; Cho, E. Niacin intake and risk of skin cancer in US women and men. Int. J. Cancer 2017, 140, 2023-2031. [CrossRef] [PubMed]

37. Tummala, K.S.; Gomes, A.L.; Yilmaz, M.; Grana, O.; Bakiri, L.; Ruppen, I.; Ximenez-Embun, P.; Sheshappanavar, V.; Rodriguez-Justo, M.; Pisano, D.G.; et al. Inhibition of de novo NAD(+) synthesis by oncogenic URI causes liver tumorigenesis through DNA damage. Cancer Cell 2014, 26, 826-839. [CrossRef]

38. Rajman, L.; Chwalek, K.; Sinclair, D.A. Therapeutic Potential of NAD-Boosting Molecules: The In Vivo Evidence. Cell Metab. 2018, 27, 529-547. [CrossRef]

39. Molenaar, R.J.; Maciejewski, J.P.; Wilmink, J.W.; van Noorden, C.J.F. Wild-type and mutated IDH1/2 enzymes and therapy responses. Oncogene 2018, 37, 1949-1960. [CrossRef]

40. Kaminska, B.; Czapski, B.; Guzik, R.; Krol, S.K.; Gielniewski, B. Consequences of IDH1/2 Mutations in Gliomas and an Assessment of Inhibitors Targeting Mutated IDH Proteins. Molecules 2019, 24, 968. [CrossRef]

41. Bergaggio, E.; Piva, R. Wild-Type IDH Enzymes as Actionable Targets for Cancer Therapy. Cancers 2019, 11, 563. [CrossRef] [PubMed]

42. Lucena-Cacace, A.; Otero-Albiol, D.; Jimenez-Garcia, M.P.; Munoz-Galvan, S.; Carnero, A. NAMPT Is a Potent Oncogene in Colon Cancer Progression that Modulates Cancer Stem Cell Properties and Resistance to Therapy through Sirt1 and PARP. Clin. Cancer Res. 2018, 24, 1202-1215. [CrossRef] [PubMed]

43. Lucena-Cacace, A.; Otero-Albiol, D.; Jimenez-Garcia, M.P.; Peinado-Serrano, J.; Carnero, A. NAMPT overexpression induces cancer stemness and defines a novel tumor signature for glioma prognosis. Oncotarget 2017, 8, 99514-99530. [CrossRef] [PubMed]

44. Hong, S.M.; Hwang, S.W.; Wang, T.; Park, C.W.; Ryu, Y.M.; Jung, J.H.; Shin, J.H.; Kim, S.Y.; Lee, J.L.; Kim, C.W.; et al. Increased nicotinamide adenine dinucleotide pool promotes colon cancer progression by suppressing reactive oxygen species level. Cancer Sci. 2019, 110, 629-638. [CrossRef] [PubMed] 
45. Espindola-Netto, J.M.; Chini, C.C.S.; Tarrago, M.; Wang, E.; Dutta, S.; Pal, K.; Mukhopadhyay, D.; Sola-Penna, M.; Chini, E.N. Preclinical efficacy of the novel competitive NAMPT inhibitor STF-118804 in pancreatic cancer. Oncotarget 2017, 8, 85054-85067. [CrossRef] [PubMed]

46. Barraud, M.; Garnier, J.; Loncle, C.; Gayet, O.; Lequeue, C.; Vasseur, S.; Bian, B.; Duconseil, P.; Gilabert, M.; Bigonnet, M.; et al. A pancreatic ductal adenocarcinoma subpopulation is sensitive to FK866, an inhibitor of NAMPT. Oncotarget 2016, 7, 53783-53796. [CrossRef] [PubMed]

47. Sun, Y.; Zhu, S.; Wu, Z.; Huang, Y.; Liu, C.; Tang, S.; Wei, L. Elevated serum visfatin levels are associated with poor prognosis of hepatocellular carcinoma. Oncotarget 2017, 8, 23427-23435. [CrossRef]

48. Burgos, E.S.; Schramm, V.L. Weak coupling of ATP hydrolysis to the chemical equilibrium of human nicotinamide phosphoribosyltransferase. Biochemistry 2008, 47, 11086-11096. [CrossRef]

49. Wang, T.; Zhang, X.; Bheda, P.; Revollo, J.R.; Imai, S.; Wolberger, C. Structure of Nampt/PBEF/visfatin, a mammalian NAD+ biosynthetic enzyme. Nat. Struct. Mol. Biol. 2006, 13, 661-662. [CrossRef]

50. Olesen, U.H.; Hastrup, N.; Sehested, M. Expression patterns of nicotinamide phosphoribosyltransferase and nicotinic acid phosphoribosyltransferase in human malignant lymphomas. APMIS 2011, 119, 296-303. [CrossRef]

51. Ju, H.Q.; Zhuang, Z.N.; Li, H.; Tian, T.; Lu, Y.X.; Fan, X.Q.; Zhou, H.J.; Mo, H.Y.; Sheng, H.; Chiao, P.J.; et al. Regulation of the Nampt-mediated NAD salvage pathway and its therapeutic implications in pancreatic cancer. Cancer Lett. 2016, 379, 1-11. [CrossRef] [PubMed]

52. Hesari, Z.; Nourbakhsh, M.; Hosseinkhani, S.; Abdolvahabi, Z.; Alipour, M.; Tavakoli-Yaraki, M.; Ghorbanhosseini, S.S.; Yousefi, Z.; Jafarzadeh, M.; Yarahmadi, S. Down-regulation of NAMPT expression by mir-206 reduces cell survival of breast cancer cells. Gene 2018, 673, 149-158. [CrossRef] [PubMed]

53. Zhang, C.; Tong, J.; Huang, G. Nicotinamide phosphoribosyl transferase (Nampt) is a target of microRNA-26b in colorectal cancer cells. PLoS ONE 2013, 8, e69963. [CrossRef] [PubMed]

54. Tome, M.E.; Frye, J.B.; Coyle, D.L.; Jacobson, E.L.; Samulitis, B.K.; Dvorak, K.; Dorr, R.T.; Briehl, M.M. Lymphoma cells with increased anti-oxidant defenses acquire chemoresistance. Exp. Ther. Med. 2012, 3, 845-852. [CrossRef]

55. Sampath, D.; Zabka, T.S.; Misner, D.L.; O’Brien, T.; Dragovich, P.S. Inhibition of nicotinamide phosphoribosyltransferase (NAMPT) as a therapeutic strategy in cancer. Pharmacol. Ther. 2015, 151, 16-31. [CrossRef]

56. Nahimana, A.; Attinger, A.; Aubry, D.; Greaney, P.; Ireson, C.; Thougaard, A.V.; Tjornelund, J.; Dawson, K.M.; Dupuis, M.; Duchosal, M.A. The NAD biosynthesis inhibitor APO866 has potent antitumor activity against hematologic malignancies. Blood 2009, 113, 3276-3286. [CrossRef]

57. Mitchell, S.R.; Larkin, K.; Grieselhuber, N.R.; Lai, T.H.; Cannon, M.; Orwick, S.; Sharma, P.; Asemelash, Y.; Zhang, P.; Goettl, V.M.; et al. Selective targeting of NAMPT by KPT-9274 in acute myeloid leukemia. Blood Adv. 2019, 3, 242-255. [CrossRef]

58. Tateishi, K.; Higuchi, F.; Miller, J.J.; Koerner, M.V.A.; Lelic, N.; Shankar, G.M.; Tanaka, S.; Fisher, D.E.; Batchelor, T.T.; Iafrate, A.J.; et al. The Alkylating Chemotherapeutic Temozolomide Induces Metabolic Stress in IDH1-Mutant Cancers and Potentiates NAD(+) Depletion-Mediated Cytotoxicity. Cancer Res. 2017, 77, 4102-4115. [CrossRef]

59. Cole, J.; Guiot, M.C.; Gravel, M.; Bernier, C.; Shore, G.C.; Roulston, A. Novel NAPRT specific antibody identifies small cell lung cancer and neuronal cancers as promising clinical indications for a NAMPT inhibitor/niacin co-administration strategy. Oncotarget 2017, 8, 77846-77859. [CrossRef]

60. Chan, M.; Gravel, M.; Bramoulle, A.; Bridon, G.; Avizonis, D.; Shore, G.C.; Roulston, A. Synergy between the NAMPT inhibitor GMX1777(8) and pemetrexed in non-small cell lung cancer cells is mediated by PARP activation and enhanced NAD consumption. Cancer Res. 2014, 74, 5948-5954. [CrossRef]

61. Feng, J.; Yan, P.F.; Zhao, H.Y.; Zhang, F.C.; Zhao, W.H.; Feng, M. Inhibitor of Nicotinamide Phosphoribosyltransferase Sensitizes Glioblastoma Cells to Temozolomide via Activating ROS/JNK Signaling Pathway. Biomed Res. Int. 2016, 2016, 1450843. [CrossRef] [PubMed]

62. Heske, C.M.; Davis, M.I.; Baumgart, J.T.; Wilson, K.; Gormally, M.V.; Chen, L.; Zhang, X.; Ceribelli, M.; Duveau, D.Y.; Guha, R.; et al. Matrix Screen Identifies Synergistic Combination of PARP Inhibitors and Nicotinamide Phosphoribosyltransferase (NAMPT) Inhibitors in Ewing Sarcoma. Clin. Cancer Res. 2017, 23, 7301-7311. [CrossRef] [PubMed] 
63. Bajrami, I.; Kigozi, A.; Van Weverwijk, A.; Brough, R.; Frankum, J.; Lord, C.J.; Ashworth, A. Synthetic lethality of PARP and NAMPT inhibition in triple-negative breast cancer cells. EMBO Mol. Med. 2012, 4, 1087-1096. [CrossRef] [PubMed]

64. Li, N.; Lopez, M.A.; Linares, M.; Kumar, S.; Oliva, S.; Martinez-Lopez, J.; Xu, L.; Xu, Y.; Perini, T.; Senapedis, W.; et al. Dual PAK4-NAMPT Inhibition Impacts Growth and Survival, and Increases Sensitivity to DNA-Damaging Agents in Waldenstrom Macroglobulinemia. Clin. Cancer Res. 2019, 25, 369-377. [CrossRef] [PubMed]

65. Grohmann, T.; Penke, M.; Petzold-Quinque, S.; Schuster, S.; Richter, S.; Kiess, W.; Garten, A. Inhibition of NAMPT sensitizes MOLT4 leukemia cells for etoposide treatment through the SIRT2-p53 pathway. Leuk. Res. 2018, 69, 39-46. [CrossRef]

66. Cagnetta, A.; Caffa, I.; Acharya, C.; Soncini, D.; Acharya, P.; Adamia, S.; Pierri, I.; Bergamaschi, M.; Garuti, A.; Fraternali, G.; et al. APO866 Increases Antitumor Activity of Cyclosporin-A by Inducing Mitochondrial and Endoplasmic Reticulum Stress in Leukemia Cells. Clin. Cancer Res. 2015, 21, 3934-3945. [CrossRef]

67. Zoppoli, G.; Cea, M.; Soncini, D.; Fruscione, F.; Rudner, J.; Moran, E.; Caffa, I.; Bedognetti, D.; Motta, G.; Ghio, R.; et al. Potent synergistic interaction between the Nampt inhibitor APO866 and the apoptosis activator TRAIL in human leukemia cells. Exp. Hematol. 2010, 38, 979-988. [CrossRef]

68. Cagnetta, A.; Cea, M.; Calimeri, T.; Acharya, C.; Fulciniti, M.; Tai, Y.T.; Hideshima, T.; Chauhan, D.; Zhong, M.Y.; Patrone, F.; et al. Intracellular NAD(+) depletion enhances bortezomib-induced anti-myeloma activity. Blood 2013, 122, 1243-1255. [CrossRef]

69. Cea, M.; Cagnetta, A.; Acharya, C.; Acharya, P.; Tai, Y.T.; Yang, C.; Lovera, D.; Soncini, D.; Miglino, M.; Fraternali-Orcioni, G.; et al. Dual NAMPT and BTK Targeting Leads to Synergistic Killing of Waldenstrom Macroglobulinemia Cells Regardless of MYD88 and CXCR4 Somatic Mutation Status. Clin. Cancer Res. 2016, 22, 6099-6109. [CrossRef]

70. Elf, A.K.; Bernhardt, P.; Hofving, T.; Arvidsson, Y.; Forssell-Aronsson, E.; Wangberg, B.; Nilsson, O.; Johanson, V. NAMPT Inhibitor GMX1778 Enhances the Efficacy of 177Lu-DOTATATE Treatment of Neuroendocrine Tumors. J. Nucl. Med. 2017, 58, 288-292. [CrossRef]

71. Zerp, S.F.; Vens, C.; Floot, B.; Verheij, M.; van Triest, B. NAD(+) depletion by APO866 in combination with radiation in a prostate cancer model, results from an in vitro and in vivo study. Radiother. Oncol. 2014, 110, 348-354. [CrossRef] [PubMed]

72. Sociali, G.; Raffaghello, L.; Magnone, M.; Zamporlini, F.; Emionite, L.; Sturla, L.; Bianchi, G.; Vigliarolo, T.; Nahimana, A.; Nencioni, A.; et al. Antitumor effect of combined NAMPT and CD73 inhibition in an ovarian cancer model. Oncotarget 2016, 7, 2968-2984. [CrossRef] [PubMed]

73. Hjarnaa, P.J.; Jonsson, E.; Latini, S.; Dhar, S.; Larsson, R.; Bramm, E.; Skov, T.; Binderup, L. CHS 828, a novel pyridyl cyanoguanidine with potent antitumor activity in vitro and in vivo. Cancer Res. 1999, 59, 5751-5757. [PubMed]

74. Ekelund, S.; Sjoholm, A.; Nygren, P.; Binderup, L.; Larsson, R. Cellular pharmacodynamics of the cytotoxic guanidino-containing drug CHS 828. Comparison with methylglyoxal-bis(guanylhydrazone). Eur. J. Pharmacol. 2001, 418, 39-45. [CrossRef]

75. Jonsson, E.; Friberg, L.E.; Karlsson, M.O.; Hassan, S.B.; Freijs, A.; Hansen, K.; Larsson, R. Determination of drug effect on tumour cells, host animal toxicity and drug pharmacokinetics in a hollow-fibre model in rats. Cancer Chemother. Pharmacol. 2000, 46, 493-500. [CrossRef]

76. Von Heideman, A.; Berglund, A.; Larsson, R.; Nygren, P. Safety and efficacy of NAD depleting cancer drugs: Results of a phase I clinical trial of CHS 828 and overview of published data. Cancer Chemother. Pharmacol. 2010, 65, 1165-1172. [CrossRef]

77. Ravaud, A.; Cerny, T.; Terret, C.; Wanders, J.; Bui, B.N.; Hess, D.; Droz, J.P.; Fumoleau, P.; Twelves, C. Phase I study and pharmacokinetic of CHS-828, a guanidino-containing compound, administered orally as a single dose every 3 weeks in solid tumours: An ECSG/EORTC study. Eur. J. Cancer 2005, 41, 702-707. [CrossRef]

78. Hovstadius, P.; Larsson, R.; Jonsson, E.; Skov, T.; Kissmeyer, A.M.; Krasilnikoff, K.; Bergh, J.; Karlsson, M.O.; Lonnebo, A.; Ahlgren, J. A Phase I study of CHS 828 in patients with solid tumor malignancy. Clin. Cancer Res. 2002, 8, 2843-2850.

79. Goldinger, S.M.; Gobbi Bischof, S.; Fink-Puches, R.; Klemke, C.D.; Dreno, B.; Bagot, M.; Dummer, R. Efficacy and Safety of APO866 in Patients With Refractory or Relapsed Cutaneous T-Cell Lymphoma: A Phase 2 Clinical Trial. JAMA Dermatol. 2016, 152, 837-839. [CrossRef] 
80. Grozio, A.; Sociali, G.; Sturla, L.; Caffa, I.; Soncini, D.; Salis, A.; Raffaelli, N.; De Flora, A.; Nencioni, A.; Bruzzone, S. CD73 protein as a source of extracellular precursors for sustained NAD+ biosynthesis in FK866-treated tumor cells. J. Biol. Chem. 2013, 288, 25938-25949. [CrossRef]

81. Tommasini-Ghelfi, S.; Murnan, K.; Kouri, F.M.; Mahajan, A.S.; May, J.L.; Stegh, A.H. Cancer-associated mutation and beyond: The emerging biology of isocitrate dehydrogenases in human disease. Sci. Adv. 2019, 5, eaaw4543. [CrossRef]

82. Brat, D.J.; Verhaak, R.G.; Aldape, K.D.; Yung, W.K.; Salama, S.R.; Cooper, L.A.; Rheinbay, E.; Miller, C.R.; Vitucci, M.; Morozova, O.; et al. Comprehensive, Integrative Genomic Analysis of Diffuse Lower-Grade Gliomas. N. Engl. J. Med. 2015, 372, 2481-2498. [PubMed]

83. Medeiros, B.C.; Fathi, A.T.; DiNardo, C.D.; Pollyea, D.A.; Chan, S.M.; Swords, R. Isocitrate dehydrogenase mutations in myeloid malignancies. Leukemia 2017, 31, 272-281. [CrossRef] [PubMed]

84. Nepal, C.; O’Rourke, C.J.; Oliveira, D.; Taranta, A.; Shema, S.; Gautam, P.; Calderaro, J.; Barbour, A.; Raggi, C.; Wennerberg, K.; et al. Genomic perturbations reveal distinct regulatory networks in intrahepatic cholangiocarcinoma. Hepatology 2018, 68, 949-963. [CrossRef] [PubMed]

85. Farshidfar, F.; Zheng, S.; Gingras, M.C.; Newton, Y.; Shih, J.; Robertson, A.G.; Hinoue, T.; Hoadley, K.A.; Gibb, E.A.; Roszik, J.; et al. Integrative Genomic Analysis of Cholangiocarcinoma Identifies Distinct IDH-Mutant Molecular Profiles. Cell Rep. 2017, 19, 2878-2880. [CrossRef] [PubMed]

86. Tedeschi, P.M.; Bansal, N.; Kerrigan, J.E.; Abali, E.E.; Scotto, K.W.; Bertino, J.R. NAD+ Kinase as a Therapeutic Target in Cancer. Clin. Cancer Res. 2016, 22, 5189-5195. [CrossRef]

87. McGuinness, E.T.; Butler, J.R. NAD+ kinase-a review. Int. J. Biochem. 1985, 17, 1-11. [CrossRef]

88. Pace, M.; Mauri, P.L.; Gardana, C.; Pietta, P.G. High-performance liquid chromatographic assay for nicotinamide-adenine dinucleotide kinase. J. Chromatogr. 1989, 476, 487-490. [CrossRef]

89. Jalouzot, R.; Pou, M.A.; Aubry, C.; Laval-Martin, D. The NAD kinase: A phosphoryltransferase displaying an oxido-reductase activity-an electrophoretic study. Arch. Biochem. Biophys. 1994, 309, 281-287. [CrossRef]

90. Lerner, F.; Niere, M.; Ludwig, A.; Ziegler, M. Structural and functional characterization of human NAD kinase. Biochem. Biophys. Res. Commun. 2001, 288, 69-74. [CrossRef]

91. Kawai, S.; Murata, K. Structure and function of NAD kinase and NADP phosphatase: Key enzymes that regulate the intracellular balance of $\mathrm{NAD}(\mathrm{H})$ and $\mathrm{NADP}(\mathrm{H})$. Biosci. Biotechnol. Biochem. 2008, 72, 919-930. [CrossRef] [PubMed]

92. Pollak, N.; Niere, M.; Ziegler, M. NAD kinase levels control the NADPH concentration in human cells. J. Biol. Chem. 2007, 282, 33562-33571. [CrossRef] [PubMed]

93. Ohashi, K.; Kawai, S.; Murata, K. Identification and characterization of a human mitochondrial NAD kinase. Nat. Commun. 2012, 3, 1248. [CrossRef] [PubMed]

94. Pescarmona, G.P.; Bracone, A.; David, O.; Sartori, M.L.; Bosia, A. Regulation of NAD and NADP synthesis in human red cell. Acta Biol. Med. Ger. 1977, 36, 759-763. [PubMed]

95. Williams, M.B.; Jones, H.P. Calmodulin-dependent NAD kinase of human neutrophils. Arch. Biochem. Biophys. 1985, 237, 80-87. [CrossRef]

96. Gray, J.P.; Alavian, K.N.; Jonas, E.A.; Heart, E.A. NAD kinase regulates the size of the NADPH pool and insulin secretion in pancreatic beta-cells. Am. J. Physiol. Endocrinol. Metab. 2012, 303, E191-E199. [CrossRef]

97. Ciccarese, F.; Ciminale, V. Escaping Death: Mitochondrial Redox Homeostasis in Cancer Cells. Front. Oncol. 2017, 7, 117. [CrossRef]

98. Perkins, J.P.; Hillcoat, B.L.; Bertino, J.R. Dihydrofolate reductase from a resistant subline of the L1210 lymphoma. Purification and properties. J. Biol. Chem. 1967, 242, 4771-4776.

99. Abali, E.E.; Skacel, N.E.; Celikkaya, H.; Hsieh, Y.C. Regulation of human dihydrofolate reductase activity and expression. Vitam. Horm. 2008, 79, 267-292.

100. Bertino, J.R. Cancer research: From folate antagonism to molecular targets. Best Pract. Res. Clin. Haematol. 2009, 22, 577-582. [CrossRef]

101. Ercikan-Abali, E.A.; Banerjee, D.; Waltham, M.C.; Skacel, N.; Scotto, K.W.; Bertino, J.R. Dihydrofolate reductase protein inhibits its own translation by binding to dihydrofolate reductase mRNA sequences within the coding region. Biochemistry 1997, 36, 12317-12322. [CrossRef]

102. Hentze, M.W. Enzymes as RNA-binding proteins: A role for (di)nucleotide-binding domains? Trends Biochem. Sci. 1994, 19, 101-103. [CrossRef] 
103. Roussel, B.; Johnson-Farley, N.; Kerrigan, J.E.; Scotto, K.W.; Banerjee, D.; Felczak, K.; Pankiewicz, K.W.; Gounder, M.; Lin, H.; Abali, E.E.; et al. A second target of benzamide riboside: Dihydrofolate reductase. Cancer Biol. Ther. 2012, 13, 1290-1298. [CrossRef] [PubMed]

104. Gustafsson Sheppard, N.; Jarl, L.; Mahadessian, D.; Strittmatter, L.; Schmidt, A.; Madhusudan, N.; Tegner, J.; Lundberg, E.K.; Asplund, A.; Jain, M.; et al. The folate-coupled enzyme MTHFD2 is a nuclear protein and promotes cell proliferation. Sci. Rep. 2015, 5, 15029. [CrossRef] [PubMed]

105. Nilsson, R.; Jain, M.; Madhusudhan, N.; Sheppard, N.G.; Strittmatter, L.; Kampf, C.; Huang, J.; Asplund, A.; Mootha, V.K. Metabolic enzyme expression highlights a key role for MTHFD2 and the mitochondrial folate pathway in cancer. Nat. Commun. 2014, 5, 3128. [CrossRef]

106. Agarwal, S.; Behring, M.; Hale, K.; Al Diffalha, S.; Wang, K.; Manne, U.; Varambally, S. MTHFD1L, A Folate Cycle Enzyme, Is Involved in Progression of Colorectal Cancer. Transl. Oncol. 2019, 12, 1461-1467. [CrossRef] [PubMed]

107. Eich, M.L.; Rodriguez Pena, M.D.C.; Chandrashekar, D.S.; Chaux, A.; Agarwal, S.; Gordetsky, J.B.; Ferguson, J.E.; Sonpavde, G.P.; Netto, G.J.; Varambally, S. Expression and Role of Methylenetetrahydrofolate Dehydrogenase 1 Like (MTHFD1L) in Bladder Cancer. Transl. Oncol. 2019, 12, 1416-1424. [CrossRef]

108. Shin, M.; Momb, J.; Appling, D.R. Human mitochondrial MTHFD2 is a dual redox cofactor-specific methylenetetrahydrofolate dehydrogenase/methenyltetrahydrofolate cyclohydrolase. Cancer Metab. 2017, 5, 11. [CrossRef]

109. Fan, J.; Ye, J.; Kamphorst, J.J.; Shlomi, T.; Thompson, C.B.; Rabinowitz, J.D. Quantitative flux analysis reveals folate-dependent NADPH production. Nature 2014, 510, 298-302. [CrossRef]

110. Ju, H.Q.; Lu, Y.X.; Chen, D.L.; Zuo, Z.X.; Liu, Z.X.; Wu, Q.N.; Mo, H.Y.; Wang, Z.X.; Wang, D.S.; Pu, H.Y.; et al. Modulation of Redox Homeostasis by Inhibition of MTHFD2 in Colorectal Cancer: Mechanisms and Therapeutic Implications. J. Natl. Cancer Inst. 2019, 111, 584-596. [CrossRef]

111. Ducker, G.S.; Rabinowitz, J.D. One-Carbon Metabolism in Health and Disease. Cell Metab. 2017, 25, $27-42$. [CrossRef] [PubMed]

112. Yang, M.; Vousden, K.H. Serine and one-carbon metabolism in cancer. Nat. Rev. Cancer 2016, 16, 650-662. [CrossRef] [PubMed]

113. Lee, G.Y.; Haverty, P.M.; Li, L.; Kljavin, N.M.; Bourgon, R.; Lee, J.; Stern, H.; Modrusan, Z.; Seshagiri, S.; Zhang, Z; et al. Comparative oncogenomics identifies PSMB4 and SHMT2 as potential cancer driver genes. Cancer Res. 2014, 74, 3114-3126. [CrossRef] [PubMed]

114. Woo, C.C.; Chen, W.C.; Teo, X.Q.; Radda, G.K.; Lee, P.T. Downregulating serine hydroxymethyltransferase 2 (SHMT2) suppresses tumorigenesis in human hepatocellular carcinoma. Oncotarget 2016, 7, 53005-53017. [CrossRef]

115. Jain, M.; Nilsson, R.; Sharma, S.; Madhusudhan, N.; Kitami, T.; Souza, A.L.; Kafri, R.; Kirschner, M.W.; Clish, C.B.; Mootha, V.K. Metabolite profiling identifies a key role for glycine in rapid cancer cell proliferation. Science 2012, 336, 1040-1044. [CrossRef]

116. Ye, J.; Fan, J.; Venneti, S.; Wan, Y.W.; Pawel, B.R.; Zhang, J.; Finley, L.W.; Lu, C.; Lindsten, T.; Cross, J.R.; et al. Serine catabolism regulates mitochondrial redox control during hypoxia. Cancer Discov. 2014, 4, 1406-1417. [CrossRef]

117. Koppaka, V.; Thompson, D.C.; Chen, Y.; Ellermann, M.; Nicolaou, K.C.; Juvonen, R.O.; Petersen, D.; Deitrich, R.A.; Hurley, T.D.; Vasiliou, V. Aldehyde dehydrogenase inhibitors: A comprehensive review of the pharmacology, mechanism of action, substrate specificity, and clinical application. Pharmacol. Rev. 2012, 64, 520-539. [CrossRef]

118. Deng, S.; Yang, X.; Lassus, H.; Liang, S.; Kaur, S.; Ye, Q.; Li, C.; Wang, L.P.; Roby, K.F.; Orsulic, S.; et al. Distinct expression levels and patterns of stem cell marker, aldehyde dehydrogenase isoform 1 (ALDH1), in human epithelial cancers. PLoS ONE 2010, 5, e10277. [CrossRef]

119. Duan, J.J.; Cai, J.; Guo, Y.F.; Bian, X.W.; Yu, S.C. ALDH1A3, a metabolic target for cancer diagnosis and therapy. Int. J. Cancer 2016, 139, 965-975. [CrossRef]

120. Aung, H.H.; Lame, M.W.; Gohil, K.; He, G.; Denison, M.S.; Rutledge, J.C.; Wilson, D.W. Comparative gene responses to collected ambient particles in vitro: Endothelial responses. Physiol. Genomics 2011, 43, 917-929. [CrossRef]

121. Vasiliou, V.; Pappa, A.; Estey, T. Role of human aldehyde dehydrogenases in endobiotic and xenobiotic metabolism. Drug Metab. Rev. 2004, 36, 279-299. [CrossRef] [PubMed] 
122. Sima, A.; Parisotto, M.; Mader, S.; Bhat, P.V. Kinetic characterization of recombinant mouse retinal dehydrogenase types 3 and 4 for retinal substrates. Biochim. Biophys. Acta 2009, 1790, 1660-1664. [CrossRef]

123. Kang, J.H.; Lee, S.H.; Hong, D.; Lee, J.S.; Ahn, H.S.; Ahn, J.H.; Seong, T.W.; Lee, C.H.; Jang, H.; Hong, K.M.; et al. Aldehyde dehydrogenase is used by cancer cells for energy metabolism. Exp. Mol. Med. 2016, 48, e272. [CrossRef] [PubMed]

124. Kim, S.Y. Cancer Energy Metabolism: Shutting Power off Cancer Factory. Biomol. Ther. (Seoul) 2018, 26, 39-44. [CrossRef] [PubMed]

125. Donato, L.J.; Noy, N. Suppression of mammary carcinoma growth by retinoic acid: Proapoptotic genes are targets for retinoic acid receptor and cellular retinoic acid-binding protein II signaling. Cancer Res. 2005, 65, 8193-8199. [CrossRef] [PubMed]

126. Jia, J.; Parikh, H.; Xiao, W.; Hoskins, J.W.; Pflicke, H.; Liu, X.; Collins, I.; Zhou, W.; Wang, Z.; Powell, J.; et al. An integrated transcriptome and epigenome analysis identifies a novel candidate gene for pancreatic cancer. BMC Med. Genomics 2013, 6, 33. [CrossRef]

127. Saw, Y.T.; Yang, J.; Ng, S.K.; Liu, S.; Singh, S.; Singh, M.; Welch, W.R.; Tsuda, H.; Fong, W.P.; Thompson, D.; et al. Characterization of aldehyde dehydrogenase isozymes in ovarian cancer tissues and sphere cultures. BMC Cancer 2012, 12, 329. [CrossRef]

128. Mao, P.; Joshi, K.; Li, J.; Kim, S.H.; Li, P.; Santana-Santos, L.; Luthra, S.; Chandran, U.R.; Benos, P.V.; Smith, L.; et al. Mesenchymal glioma stem cells are maintained by activated glycolytic metabolism involving aldehyde dehydrogenase 1A3. Proc. Natl. Acad. Sci. USA 2013, 110, 8644-8649. [CrossRef]

129. Shames, D.S.; Girard, L.; Gao, B.; Sato, M.; Lewis, C.M.; Shivapurkar, N.; Jiang, A.; Perou, C.M.; Kim, Y.H.; Pollack, J.R.; et al. A genome-wide screen for promoter methylation in lung cancer identifies novel methylation markers for multiple malignancies. PLoS Med. 2006, 3, e486. [CrossRef]

130. Kim, Y.J.; Yoon, H.Y.; Kim, J.S.; Kang, H.W.; Min, B.D.; Kim, S.K.; Ha, Y.S.; Kim, I.Y.; Ryu, K.H.; Lee, S.C.; et al. HOXA9, ISL1 and ALDH1A3 methylation patterns as prognostic markers for nonmuscle invasive bladder cancer: Array-based DNA methylation and expression profiling. Int. J. Cancer 2013, 133, 1135-1142. [CrossRef]

131. Zhang, W.; Yan, W.; You, G.; Bao, Z.; Wang, Y.; Liu, Y.; You, Y.; Jiang, T. Genome-wide DNA methylation profiling identifies ALDH1A3 promoter methylation as a prognostic predictor in G-CIMP- primary glioblastoma. Cancer Lett. 2013, 328, 120-125. [CrossRef] [PubMed]

132. Perez-Alea, M.; McGrail, K.; Sanchez-Redondo, S.; Ferrer, B.; Fournet, G.; Cortes, J.; Munoz, E.; Hernandez-Losa, J.; Tenbaum, S.; Martin, G.; et al. ALDH1A3 is epigenetically regulated during melanocyte transformation and is a target for melanoma treatment. Oncogene 2017, 36, 5695-5708. [CrossRef] [PubMed]

133. Shao, C.; Sullivan, J.P.; Girard, L.; Augustyn, A.; Yenerall, P.; Rodriguez-Canales, J.; Liu, H.; Behrens, C.; Shay, J.W.; Wistuba, I.I.; et al. Essential role of aldehyde dehydrogenase 1A3 for the maintenance of non-small cell lung cancer stem cells is associated with the STAT3 pathway. Clin. Cancer Res. 2014, 20, 4154-4166. [CrossRef] [PubMed]

134. Luo, Y.; Dallaglio, K.; Chen, Y.; Robinson, W.A.; Robinson, S.E.; McCarter, M.D.; Wang, J.; Gonzalez, R.; Thompson, D.C.; Norris, D.A.; et al. ALDH1A isozymes are markers of human melanoma stem cells and potential therapeutic targets. Stem Cells 2012, 30, 2100-2113. [CrossRef] [PubMed]

135. Golubovskaya, V.; O’Brien, S.; Ho, B.; Heffler, M.; Conroy, J.; Hu, Q.; Wang, D.; Liu, S.; Cance, W.G. Down-regulation of ALDH1A3, CD44 or MDR1 sensitizes resistant cancer cells to FAK autophosphorylation inhibitor Y15. J. Cancer Res. Clin. Oncol. 2015, 141, 1613-1631. [CrossRef] [PubMed]

136. Kang, J.H.; Lee, S.H.; Lee, J.S.; Nam, B.; Seong, T.W.; Son, J.; Jang, H.; Hong, K.M.; Lee, C.; Kim, S.Y. Aldehyde dehydrogenase inhibition combined with phenformin treatment reversed NSCLC through ATP depletion. Oncotarget 2016, 7, 49397-49410. [CrossRef] [PubMed]

137. Chen, J.; Chen, Y.; Chen, Z. MiR-125a/b regulates the activation of cancer stem cells in paclitaxel-resistant colon cancer. Cancer Invest. 2013, 31, 17-23. [CrossRef]

(C) 2020 by the authors. Licensee MDPI, Basel, Switzerland. This article is an open access article distributed under the terms and conditions of the Creative Commons Attribution (CC BY) license (http://creativecommons.org/licenses/by/4.0/). 